\title{
TOWARD A BETTER WORLD
}

Memoirs of a Life in International and Development Economics 
This page intentionally left blank 


\section{Toward a Better World}

Memoirs of a Life in International and Development Economics

GERRY HELLEINER

UNIVERSITY OF TORONTO PRESS

Toronto Buffalo London 
(C) University of Toronto Press 2018

Toronto Buffalo London

www.utorontopress.com

Printed in the U.S.A.

ISBN 978-1-4875-0221-8

6 Printed on acid-free, $100 \%$ post-consumer recycled paper with vegetable-based inks.

\section{Library and Archives Canada Cataloguing in Publication}

Helleiner, Gerald K. (Gerald Karl), 1936-, author

Toward a better world : memoirs of a life in international and development economics / Gerry Helleiner.

Includes bibliographical references and index.

ISBN 978-1-4875-0221-8 (cloth)

1. Helleiner, Gerald K. (Gerald Karl), 1936-. 2. Economists - Canada - Biography.

3. Economic development - Africa. 4. Economic developmentInternational cooperation. 5. Africa - Economic conditions - 20th century. 6. Autobiographies. I. Title.

HB121.H45A3 $2017 \quad 330.092 \quad$ C2017-906626-9

University of Toronto Press acknowledges the financial assistance to its publishing program of the Canada Council for the Arts and the Ontario Arts Council, an agency of the Government of Ontario.

Canada Council for the Arts
Conseil des Arts du Canada

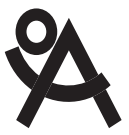

ONTARIO ARTS COUNCIL CONSEIL DES ARTS DE L'ONTARIO

an Ontario government agency un organisme du gouvernement de l'Ontario
Funded by the Government of Canada

Financé par le gouvernement du Canada 
To Kieran, Tomas, Zoe, Nels, Jannik, and Lotta 
This page intentionally left blank 